\author{
Correspondence \\ Dimitry Yu. Sorokin \\ soroc@inmi.host.ru \\ or \\ D.Y.Sorokin@tnw.tudelft.nl
}

\section{Methylohalomonas lacus gen. nov., sp. nov. and Methylonatrum kenyense gen. nov., sp. nov., methylotrophic gammaproteobacteria from hypersaline lakes}

\author{
Dimitry Yu. Sorokin, ${ }^{1,2}$ Yuri A. Trotsenko, ${ }^{3}$ Nina V. Doronina, ${ }^{3}$ Tatjana \\ P. Tourova, ${ }^{1}$ Erwin A. Galinski, ${ }^{4}$ Tatjana V. Kolganova ${ }^{5}$ and Gerard Muyzer ${ }^{2}$
}

\author{
${ }^{1}$ Winogradsky Institute of Microbiology, Russian Academy of Sciences, Prospect 60-let Octyabrya \\ 7/2, 117811 Moscow, Russia \\ ${ }^{2}$ Department of Biotechnology, Delft University of Technology, Julianalaan 67, 2628 BC Delft, \\ The Netherlands \\ ${ }^{3}$ G. K. Skryabin Institute of Biochemistry and Physiology of Microorganisms, \\ Russian Academy of Sciences, Pushchino, Russia \\ ${ }^{4}$ Institute of Microbiology and Biotechnology, Rheinische Friedrich-Wilhelms University, \\ Meckenheimer Allee 168, 53115 Bonn, Germany \\ ${ }^{5}$ Center Bioengineering, Russian Academy of Sciences, Prospect 60-let Octyabrya 7/1, \\ 117312 Moscow, Russia
}

\begin{abstract}
Aerobic enrichment at $4 \mathrm{M} \mathrm{NaCl}, \mathrm{pH} 7.5$, with methanol as carbon and energy source from sediments of hypersaline chloride-sulfate lakes in Kulunda Steppe (Altai, Russia) resulted in the isolation of a moderately halophilic and obligately methylotrophic bacterium, strain $\mathrm{HMT}^{\top}$. The bacterium grew with methanol and methylamine within a $\mathrm{pH}$ range of 6.8-8.2 with an optimum at $\mathrm{pH} 7.5$ and at $\mathrm{NaCl}$ concentrations of $0.5-4 \mathrm{M}$ with an optimum at $2 \mathrm{M}$. In addition to methanol and methylamine, it can oxidize ethanol, formate, formaldehyde and dimethylamine. Carbon is assimilated via the serine pathway. The main compatible solute is glycine betaine. 16S rRNA gene sequence analysis placed the isolate as a new lineage in the family Ectothiorhodospiraceae (Gammaproteobacteria). It is proposed, therefore, to accommodate this bacterium within a novel genus and species, Methylohalomonas lacus gen. nov., sp. nov., with HMT $1^{\top}$ (=DSM $15733^{\top}$ $=$ NCCB $100208^{\top}=$ UNIQEM U237 ${ }^{\top}$ ) as the type strain. Two strains were obtained in pure culture from sediments of soda lake Magadi in Kenya and the Kulunda Steppe (Russia) on a mineral medium at $\mathrm{pH} 10$ containing $0.6 \mathrm{M}$ total $\mathrm{Na}^{+}$using methanol as a substrate. Strain AMT $1^{\top}$ was enriched with methanol, while strain AMT 3 originated from an enrichment culture with CO. The isolates are restricted facultative methylotrophs, capable of growth with methanol, formate and acetate as carbon and energy sources. With methanol, the strains grew within a

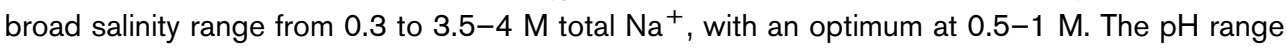
for growth was between 8.3 and 10.5, with an optimum at $\mathrm{pH} 9.5$, which characterized the soda lake isolates as obligate haloalkaliphiles. Carbon is assimilated autotrophically via the CalvinBenson cycle. Sequence analysis of the gene coding for the key enzyme RuBisCO demonstrated that strain AMT $1^{\top}$ possessed a single $c b b L$ gene of the 'green' form I, clustering with members of the family Ectothiorhodospiraceae. Analysis of the 16S rRNA gene sequence showed that strains AMT $1^{\top}$ and AMT 3 belong to a single species that forms a separate lineage within the family
\end{abstract} and EU006088, respectively. Those for the cbbL gene from AMT $1^{\top}$ and for the $m x a F$ gene from HMT $1^{\top}$ are respectively EF152335 and EF152336. Fatty acid compositions of isolates AMT $1^{\top}$ and HMT $1^{\top}$ and results of PCR amplifications of $m x a F$ with four different primer sets from (halo)alkaliphilic methylotrophs are available as supplementary material with the online version of this paper. 
Ectothiorhodospiraceae. On the basis of phenotypic and genetic data, the novel haloalkaliphilic methylotrophs are described as representing a novel genus and species, Methylonatrum kenyense gen. nov., sp. nov. (type strain AMT $1^{\top}=\mathrm{DSM} 15732^{\top}=\mathrm{NCCB} 100209^{\top}=\mathrm{UNIQEM}$ $\left.\mathrm{U} 238^{\top}\right)$.

Hypersaline inland lakes occur as two major types: chloride-sulfate lakes, with a neutral to slightly alkaline $\mathrm{pH}$ (6-8.5), and soda lakes, where the presence of free carbonate/bicarbonate can reach molar concentrations, resulting in the accumulation of highly alkaline brines with a $\mathrm{pH}$ from 9.5 to 11 . Both lake types are populated almost entirely by prokaryotes belonging to specialized (halo)alkaliphilic ecotypes. Most of these lakes are highly productive, with nitrogen-fixing (halo)alkaliphilic cyanobacteria as dominant primary producers. Various types of (halo)alkaliphilic anaerobic prokaryotes, including fermentative bacteria, methanogens and sulfate-reducing bacteria, are responsible for the complete degradation of organic matter, resulting in the formation of sulfide and methane as final products (Oren, 2002; Zavarzin et al., 1999). Methanotrophic and methylotrophic bacteria utilize the $\mathrm{C}_{1}$ compounds produced from anaerobic degradation of organic matter, thus closing the carbon cycle. Furthermore, in hypersaline habitats, the total flux of methylated compounds is enhanced by their formation as a degradation product from osmolytes, such as glycine betaine and dimethyl sulfoniopropionate. Also, haloalkaliphilic methanotrophic bacteria are known to excrete substantial amounts of $\mathrm{C}_{1}$ intermediates during methane oxidation (Trotsenko \& Khmelenina, 2002a, b). Measurements with ${ }^{14} \mathrm{C}_{1}$ compounds have demonstrated low but detectable rates of degradation in sediments of hypersaline lakes, indicating the presence of methano- and methylotrophic bacteria active under high salt conditions (Oremland et al., 1982; Sokolov \& Trotsenko, 1995; Namsaraev et al., 1999; Joye et al., 1999; Sorokin et al., 2004). Nevertheless, the (halo)alkaliphilic methano- and methylotrophic bacteria isolated so far in pure culture from saline lakes all belong to a low-salt-tolerant type (Trotsenko \& Khmelenina, 2002a, b; Heyer et al., 2005; Doronina et al., 2000, 2001, 2003a, b). The only exception is a halophilic methanotroph, Methylohalobius crimeensis $10 \mathrm{Ki}^{\mathrm{T}}$, capable of growth with up to $15 \% \mathrm{NaCl}$ (Heyer et al., 2005).

In this paper, we describe the isolation and properties of two novel species of methylotrophic gammaproteobacteria from hypersaline lakes capable of growth with $C_{1}$ compounds up to salt-saturating conditions.

The Kulunda Steppe (Altai, Russia) harbours numerous salt lakes with a total salt content from 10 to $38 \%$ and a $\mathrm{pH}$ of 7.0-8.5, with $\mathrm{Na}^{+}, \mathrm{Mg}^{2+}, \mathrm{Cl}^{-}$and $\mathrm{SO}_{4}^{2-}$ as the dominant ions in the brines. Samples of the top $10 \mathrm{~cm}$ of sediment with overlying brine water from ten lakes were mixed and used as an inoculum to enrich for halophilic methylotrophic bacteria. A sediment sample from the hypersaline soda lake Magadi (Kenya), pH 10.5 and total salt content of $22 \%$, was used to enrich for haloalkaliphilic methylotrophs.

The mineral base medium used for enrichment of halophilic methylotrophs included $4 \mathrm{M} \mathrm{NaCl}, 10 \mathrm{mM}$ $\mathrm{K}_{2} \mathrm{HPO}_{4}$ and $5 \mathrm{mM}\left(\mathrm{NH}_{4}\right)_{2} \mathrm{SO}_{4}$, final $\mathrm{pH}$ 7.2. The mineral base for haloalkaliphiles contained sodium carbonate/ bicarbonate buffer, $\mathrm{pH} 10$, containing $0.6-4 \mathrm{M}$ total $\mathrm{Na}^{+}, 0.1 \mathrm{M} \mathrm{NaCl}, 10 \mathrm{mM} \mathrm{K} \mathrm{HPO}_{4}$ and $5 \mathrm{mM} \mathrm{KNO}$. After sterilization, the media were supplemented with $1 \mathrm{mM} \mathrm{MgSO}_{4} \cdot 7 \mathrm{H}_{2} \mathrm{O}, 1 \mathrm{ml}$ trace metal solution $1^{-1}$ (Pfennig \& Lippert, 1966), $100 \mu \mathrm{g}$ vitamin $\mathrm{B}_{12} \mathrm{l}^{-1}$ and $10 \mathrm{mM} \mathrm{NaHCO}$. Methanol $(25 \mathrm{mM})$ served as the electron donor and carbon source. In an enrichment with $\mathrm{CO}$ as the only carbon and energy source from Kulunda Steppe lakes, methanol was replaced with $5 \% \mathrm{CO}$ in the gas phase $(10 \mathrm{mM})$. After several consecutive additions of $\mathrm{CO}$, the culture was transferred into medium with methanol. The incubation temperature was $30^{\circ} \mathrm{C}$. The isolation strategy included several 1:100 transfers to stabilize the cultures, serial dilutions and plating onto solid medium prepared by mixing at $50{ }^{\circ} \mathrm{C}$ of equal volumes of the liquid mineral base medium, indicated above, and $4 \%(\mathrm{w} / \mathrm{v})$ Noble agar (Difco). The plates were incubated in closed jars at $5 \% \mathrm{O}_{2}$. Autotrophic growth with hydrogen as electron donor was studied at optimal $\mathrm{pH}$ and salt using $100 \mathrm{ml}$ serum bottles with $20 \mathrm{ml}$ medium under an atmosphere of $50 \%$ air and $50 \% \mathrm{H}_{2}$. To test for anaerobic growth with methanol $(25 \mathrm{mM})$ and nitrate $(20 \mathrm{mM}), 80 \mathrm{ml}$ medium was used in $100 \mathrm{ml}$ serum bottles with argon in the gas phase.

Growth was monitored by measuring the $\mathrm{OD}_{600}$ and by cell protein analysis with the Lowry method. Respiration rates of washed cells were measured in mineral buffers corresponding to the growth medium composition without nitrogen sources using a Biological oxygen monitor (Yellow Spring Inc.). Activity of the key methylotrophic enzymes in cell-free extracts and the composition of membrane lipids and fatty acids were analysed as described previously (Doronina et al., 1995, 2003a). The composition of compatible solutes in the halophilic isolate HMT $1^{\mathrm{T}}$ was analysed by an HPLC $/{ }^{13} \mathrm{C}$-NMR method according to Galinski \& Herzog (1990). Phase-contrast photomicrographs were obtained using a Zeiss Axioplan Imaging 2 microscope. For electron microscopy, cells were fixed with glutaraldehyde (final, $3 \% \mathrm{v} / \mathrm{v}$ ) and positively contrasted with $1 \%(\mathrm{w} / \mathrm{v})$ uranyl acetate. For thin sectioning, the cells were fixed in $1 \%(\mathrm{w} / \mathrm{v}) \mathrm{OsO}_{4}$ solution containing $0.5-$ 1.0 M NaCl, dehydrated, embedded in resin and stained with uranyl acetate and lead citrate after sectioning. The 
isolation of DNA and subsequent determination of the $\mathrm{G}+\mathrm{C}$ content and DNA-DNA hybridization were performed by the thermal denaturation/reassociation technique (Marmur, 1961; De Ley et al., 1970).

For molecular analysis, genomic DNA was extracted from cells using the UltraClean Soil DNA extraction kit (Mo Bio Laboratories), following the manufacturer's instructions. Nearly complete $16 \mathrm{~S}$ rRNA genes were amplified by PCR from pure cultures using bacterial primers GM3F and GM4R (Schäfer \& Muyzer, 2001). To amplify the $c b b L$ gene, coding for the RuBisCO large subunit, a specially designed primer pair and protocol was employed (Spiridonova et al., 2004). Amplification of the mxaF gene, coding for methanol dehydrogenase, was performed with four different primer sets (McDonald \& Murrell, 1997; Dedysh et al., 2005). The sequences obtained in this study were first compared to sequences stored in GenBank using the BLAST algorithm (http://www.ncbi.nlm.nih.gov/ BLAST). The nucleotide and inferred amino acid sequences were aligned with sequences from GenBank using CLUSTAL w. Phylogenetic trees were reconstructed using the TREECONW (Van de Peer \& De Wachter, 1994) and PHYLIP 3.5c (Felsenstein, 1993) program packages with four different algorithms: neighbour-joining, maximum-parsimony, distance matrix and maximum-likelihood.
The enrichment with methanol at $4 \mathrm{M} \mathrm{NaCl}$ using a mixture of sediment samples from hypersaline Siberian lakes resulted in the domination of rod-shaped bacteria, which were further purified by serial dilutions and eventually isolated in pure culture from a single colony on plates containing $2 \mathrm{M} \mathrm{NaCl}$ and methanol as strain HMT $1^{\mathrm{T}}$. Among the enrichments from Lake Magadi at $\mathrm{pH} 10$ with methanol as substrate, positive results were obtained only at low salt $\left(0.6-1.0 \mathrm{M}\right.$ total $\mathrm{Na}^{+}$, but not at 3-4 M), resulting in isolation of strain AMT $1^{\mathrm{T}}$. Another haloalkaliphilic methylotroph, strain AMT 3, was obtained from an enrichment inoculated with a mixed sediment sample from Kulunda Steppe hypersaline soda lakes where $\mathrm{CO}$ served as the only substrate. AMT 3 was a minor satellite component of that enrichment, but it became dominant after transfer into the medium with methanol.

Cells of all three isolates were short, non-motile rods with a Gram-negative type of cell wall (Fig. 1). Cells of strain HMT $1^{\mathrm{T}}$ were covered with an exopolysaccharide (EPS)like substance.

Strain HMT $1^{\mathrm{T}}$ belonged to the obligate methylotrophs, utilizing only methanol and methylamine as growth substrates. In contrast, the soda lake isolates, in addition to utilizing methanol (AMT $1^{\mathrm{T}}$, AMT 3) and formate (AMT 3), also grew on acetate and ethanol and therefore
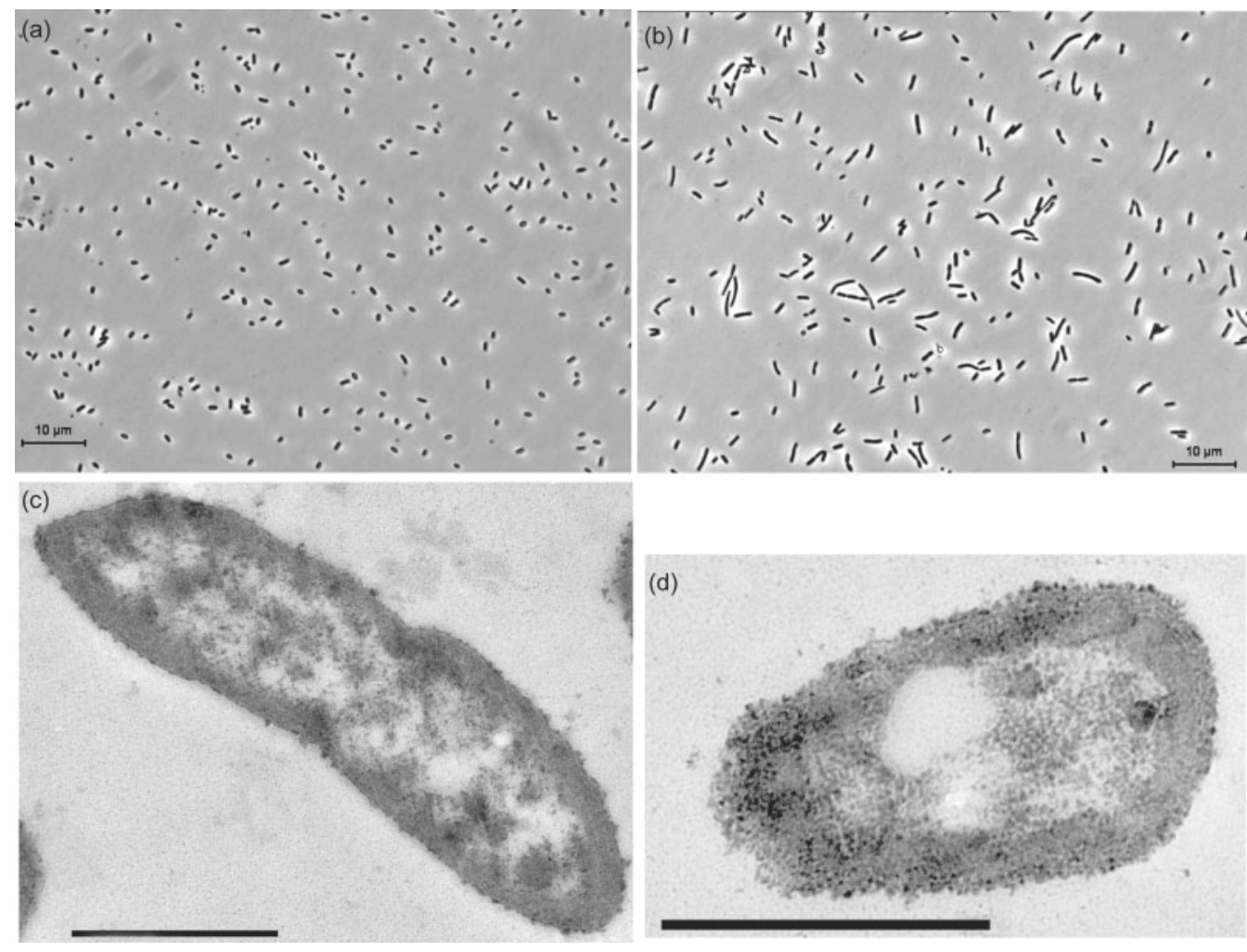

Fig. 1. Cell morphology of haloalkaliphilic strain $\operatorname{AMT} 1^{\top}(a, c)$ and halophilic strain $\operatorname{HMT} 1^{\top}(b, d)$ from hypersaline lakes. $(a, b)$ Phase-contrast photomicrographs; (c, d) thin sections. Bars, $10 \mu \mathrm{m}(\mathrm{a}, \mathrm{b})$ and $1 \mu \mathrm{m}(\mathrm{c}, \mathrm{d})$. 
can be considered as restricted methylotrophs. According to its $\mathrm{pH}$ and salt response, the salt lake isolate HMT $1^{\mathrm{T}}$ is a neutrophilic, extremely salt-tolerant moderate halophile. To our knowledge, it represents the first halophilic, methylotrophic bacterium capable of growth with $\mathrm{C}_{1}$ compounds up to $4 \mathrm{M} \mathrm{NaCl}$. The soda lake isolates are typical haloalkaliphiles, with a relatively narrow alkaline $\mathrm{pH}$ range for growth and an optimum at $\mathrm{pH} 10$. Although isolated at low salt, in pure culture, strains AMT $1^{\mathrm{T}}$ and AMT 3 grew with methanol and acetate in saturated soda brines (3.5-4 M total $\mathrm{Na}^{+}$). This makes these strains unique among the haloalkaliphilic methylotrophs obtained from soda lakes so far. It needs to be mentioned, however, that, for all isolates, the growth rate at $3.5-4 \mathrm{M} \mathrm{Na}^{+}$was only $5-10 \%$ of the maximum ( $\mu_{\max }$ with methanol 0.045 and $0.02-0.035 \mathrm{~h}^{-1}$ for halophilic strain HMT $1^{\mathrm{T}}$ and haloalkaliphilic strains AMT $1^{\mathrm{T}}$ and AMT 3, respectively), and the growth yield decreased by a factor of 2-2.5. This indicates highly stressed growth conditions. Autotrophic growth was not observed either with hydrogen or thiosulfate as electron donor, and anaerobic growth was not observed with nitrate. Respiration activity tests using washed cells demonstrated that, apart from methanol and its oxidation products (i.e. formate and formaldehyde), all three isolates can also oxidize ethanol. Furthermore, cells of HMT $1^{\mathrm{T}}$ induced methyl- and dimethylamine-oxidizing capacity when grown with methylamine, while still keeping the potential to oxidize methanol. On the other hand, growth of strains AMT $1^{\mathrm{T}}$ and AMT 3 with acetate led to repression of the methanol dehydrogenase system and induction of acetate-dependent respiration, while retaining high activities of formaldehyde oxidation (Table 1). The maximum rate of methanol-dependent respiration activity for halophilic strain HMT $1^{\mathrm{T}}$ was observed at $\mathrm{pH} 8$ and $2 \mathrm{M} \mathrm{NaCl}$ and at $\mathrm{pH} 10$ and $0.5-0.75 \mathrm{M}^{2}$ total $\mathrm{Na}^{+}$for the haloalkaliphilic strains AMT $1^{\mathrm{T}}$ and AMT 3.

Measurements of the activity of key enzymes of $\mathrm{C}_{1}$ metabolism (Table 2) identified the presence of methanol-catabolizing dehydrogenases in strains HMT $1^{\mathrm{T}}$ and
AMT $1^{\mathrm{T}}$. However, their carbon assimilation pathways were different. In halophilic strain HMT $1^{\mathrm{T}}$, the key enzymes of the serine pathway (hydroxypyruvate reductase and serine-glyoxylate aminotransferase) were detected. In contrast, the haloalkaliphilic strain AMT $1^{\mathrm{T}}$ is an autotroph, with the Calvin-Benson cycle and RuBisCO and phosphoribulokinase as the key enzymes.

Lipid analysis revealed the presence of cardiolipin, phosphatidylethanolamine and phosphatidylserine as the major membrane phospholipids in strains HMT $1^{\mathrm{T}}$ and AMT $1^{\mathrm{T}}$. However, the cellular fatty acid compositions were very different in the two strains (Supplementary Table S1, available in IJSEM Online). The fatty acid profile in the haloalkaliphilic methylotroph AMT $1^{\mathrm{T}}$ was very similar to that of the low-salt-tolerant, alkaliphilic, sulfur-oxidizing autotroph Thioalkalimicrobium aerophilum, isolated from the same habitats (Banciu et al., 2005), with an absolute dominance of $\mathrm{C}_{18: 1} \omega 7$. In the neutrophilic halophile HMT $1^{\mathrm{T}}$, saturated species were dominant, with $\mathrm{C}_{16: 0}$ as a predominant component and cyc $\mathrm{C}_{17: 0}$ and 10-methyl $\mathrm{C}_{16: 0}$ as secondary dominant components. While the former is quite common for halophiles (Vargas et al., 2005), the abundance of cyc $\mathrm{C}_{17: 0}$ and complete absence of $\mathrm{C}_{18: 1}$ species is certainly unusual. As for the third abundant species, 10-methyl $\mathrm{C}_{16: 0}$, our recent work with two new groups of extremely halophilic, sulfur-oxidizing gammaproteobacteria obtained from the same habitats (Sorokin et al., 2006) identified it as a dominant fatty acid in their polar membrane lipids. Analysis of organic compatible solute composition accumulated by the cells of halophilic strain HMT $1^{\mathrm{T}}$ grown with methanol at $2 \mathrm{M} \mathrm{NaCl}$ demonstrated the presence of glycine betaine as the dominant species, constituting approximately $17 \%$ of the total cell mass. This solute and its specific content are typical for high-salt-tolerant (halo)alkaliphilic gammaproteobacteria (Galinski \& Trüper, 1994).

The $\mathrm{G}+\mathrm{C}$ contents in the genomic DNA of strains AMT $1^{\mathrm{T}}$, AMT 3 and HMT $1^{\mathrm{T}}$ were 59.6, 59.0 and $62.9 \mathrm{~mol} \%\left(T_{\mathrm{m}}\right)$, respectively. Phylogenetic analysis based on sequencing of

Table 1. Respiration activity of washed cells of (halo)alkaliphilic methylotrophic isolates

Cells were incubated under the same conditions of $\mathrm{pH}$ and salt composition with the $\mathrm{C}_{1}$ compound shown. Strains AMT $1^{\mathrm{T}}$ and AMT 3 were grown at $\mathrm{pH} 10$ and $0.6 \mathrm{M} \mathrm{Na}^{+}$, while strain HMT $1^{\mathrm{T}}$ was grown at $\mathrm{pH} 7.5$ and $2 \mathrm{M} \mathrm{NaCl}$ Values are $\mathrm{nmol} \mathrm{O}_{2}\left(\mathrm{mg} \mathrm{protein}^{-1} \mathrm{~min}^{-1}\right.$.

\begin{tabular}{|c|c|c|c|c|c|c|c|}
\hline \multirow[t]{2}{*}{ Substrate } & \multicolumn{2}{|c|}{ AMT $1^{T}$} & \multicolumn{3}{|c|}{ AMT 3} & \multicolumn{2}{|c|}{ HMT $1^{T}$} \\
\hline & Methanol & Acetate & Methanol & Formate & Acetate & Methanol & Methylamine \\
\hline Formaldehyde & 380 & 350 & 320 & 200 & 250 & 60 & 80 \\
\hline Formate & 150 & 80 & 210 & 250 & 92 & 15 & 8 \\
\hline Ethanol & 80 & 25 & 70 & 0 & 25 & 45 & 64 \\
\hline Dimethylamine & 0 & 0 & 0 & 0 & 0 & 0 & 136 \\
\hline Trimethylamine & 0 & 0 & 0 & 0 & 0 & 0 & 4 \\
\hline
\end{tabular}


Table 2. Enzyme activities in cell-free extracts of methylotrophic extremophilic bacteria

The growth substrate was methanol. Cells were incubated under the same conditions of $\mathrm{pH}$ and salt as in the growth media. Activities are given as nmol (mg protein $)^{-1} \mathrm{~min}^{-1}$. Strain AMT $1^{\mathrm{T}}$ was grown at $\mathrm{pH} 10$ and $0.6 \mathrm{M} \mathrm{Na}^{+}$and strain HMT $1^{\mathrm{T}}$ was grown at $\mathrm{pH} 7.5$ and $2 \mathrm{M} \mathrm{NaCl}$. GSH, Reduced glutathione; PMS, phenazine methosulfate.

\begin{tabular}{|c|c|c|}
\hline Enzyme (cofactor) & AMT $1^{T}$ & HMT $1^{T}$ \\
\hline Methanol dehydrogenase (PMS) & 124 & 180 \\
\hline \multicolumn{3}{|l|}{ Formaldehyde dehydrogenase } \\
\hline (PMS) & 176 & 85 \\
\hline$\left(\mathrm{NAD}^{+}, \mathrm{GSH}\right)$ & 0 & 0 \\
\hline \multicolumn{3}{|l|}{ Formate dehydrogenase } \\
\hline (PMS) & 95 & 15 \\
\hline$\left(\mathrm{NAD}^{+}\right)$ & 0 & 10 \\
\hline \multicolumn{3}{|l|}{ Hydroxypyruvate reductase } \\
\hline$(\mathrm{NADH})$ & 0 & 120 \\
\hline (NADPH) & 0 & 22 \\
\hline \multicolumn{3}{|l|}{ Serine-glyoxylate aminotransferase } \\
\hline$(\mathrm{NADH})$ & 0 & 107 \\
\hline (NADPH) & 0 & 10 \\
\hline 3-Hexulose-phosphate synthase & 0 & 0 \\
\hline Phosphoribulokinase & 63 & 0 \\
\hline RuBisCO & 79 & 0 \\
\hline
\end{tabular}

the 16S rRNA gene placed the extremophilic methylotrophs into the family Ectothiorhodospiraceae. According to this analysis, the AMT strains clearly belonged to the same species ( $99.7 \%$ sequence similarity). The group was loosely associated with sequences from non-phototrophic members of the Ectothiorhodospiraceae, such as the Alkalispirillum-Alkalilimnicola group, Aquisalina and Arhodomonas aquaeolei (Fig. 2). The nearest culturable relative of the halophilic strain HMT $1^{\mathrm{T}}$ is the haloalkaliphilic sulfur-oxidizing bacterium Thioalkalispira microaerophila ALEN $1^{\mathrm{T}}$, isolated from a soda lake (Sorokin et al., 2002). It must be noted that HMT $1^{\mathrm{T}}$ represents the first example of a methylotroph with the serine pathway of carbon assimilation within the Gammaproteobacteria. In both cases, the level of $16 \mathrm{~S}$ rRNA gene sequence similarity with the nearest relatives was below $95 \%$.

Since both the alkaliphilic and halophilic isolates formed deep lineages with uncertain branching, key functional genes $c b b L$ (RuBisCO) for the alkaliphilic strain AMT $1^{\mathrm{T}}$ and $m x a F$ (methanol dehydrogenase) for both groups were also analysed. A single $c b b L$ gene of the 'green-like' form I RuBisCO was detected in AMT $1^{\mathrm{T}}$. Phylogenetic analysis placed the sequence within the Thioalkalivibrio cluster in the Ectothiorhodospiraceae, consistent with the 16S rRNA gene phylogeny (Fig. 3a). The mxaF gene was easily detectable in the halophilic isolate HMT $1^{\mathrm{T}}$, but all attempts to amplify the gene from the AMT strains, using four different primer sets, failed (Supplementary Fig. S1). This might indicate that the enzyme in this autotrophic

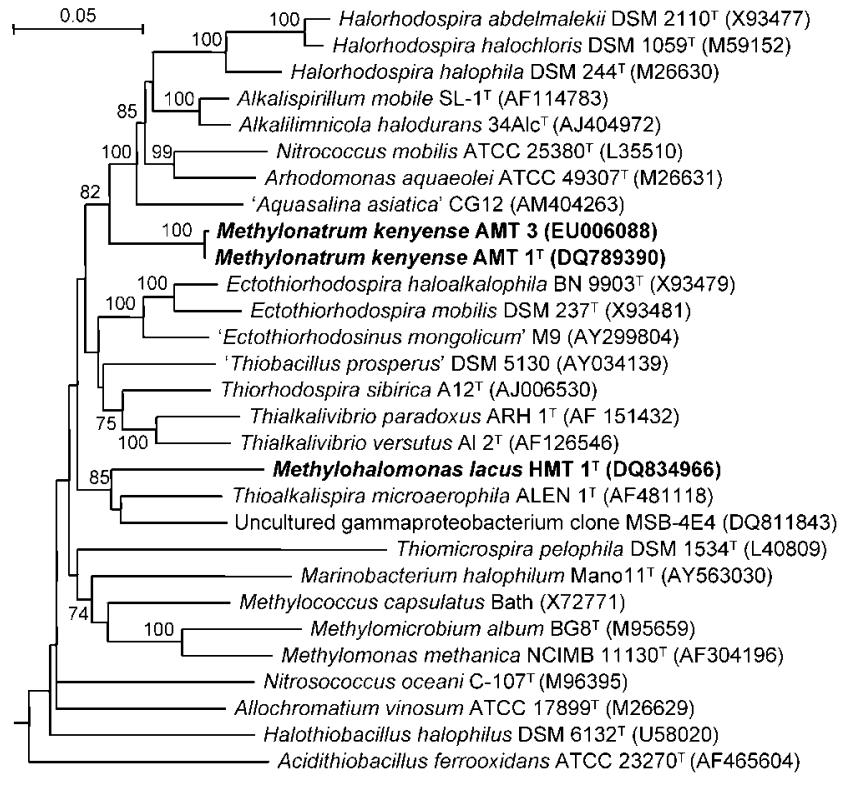

Fig. 2. Neighbour-joining tree based on 16S rRNA gene sequences showing the phylogenetic affiliations of (halo)alkaliphilic methylotrophic isolates from hypersaline lakes within the Gammaproteobacteria. Bar, 5\% sequence variation. Bootstrap values indicated at nodes are presented only when they exceed $70 \%$.

methylotroph is different from the classical methanol dehydrogenase. Phylogenetic analysis of the partial $m x a F$ sequence from HMT $1^{\mathrm{T}}$ placed it between beta- and gammaproteobacterial methylotrophs as a separate branch, which confirmed its separate position among known methylotrophs (Fig. 3b).

On the basis of phenotypic and genetic properties, the novel (halo)alkaliphilic methylotrophic gammaproteobacteria isolated from hypersaline lakes are proposed to be assigned into two new genera and species. For the halophilic neutrophilic strain HMT $1^{\mathrm{T}}$, the name Methylohalomonas lacus gen. nov., sp. nov. is proposed, and the name Methylonatrum kenyense gen. nov., sp. nov. is proposed for the haloalkaliphilic strains AMT $1^{\mathrm{T}}$ and AMT 3. Their essential properties in comparison with known (halo)alkaliphilic methylotrophs are presented in Table 3.

\section{Description of Methylohalomonas gen. nov.}

Methylohalomonas [Me.thy'lo.ha.lo.mo'nas. N.Gr. n. methyl (from Gr. n. methu wine and Gr. n. hulê wood) the methyl radical; Gr. n. hals, halos salt; Gr. fem. n. monas a unit, monad; N.L. fem. n. Methylohalomonas salt (-tolerant), methyl-group-utilizing monad].

Cells are Gram-negative rods. Obligately methylotrophic. Utilize $\mathrm{C}_{1}$ compounds as carbon and energy sources using the serine cycle for carbon assimilation. Halophilic and 
(a)

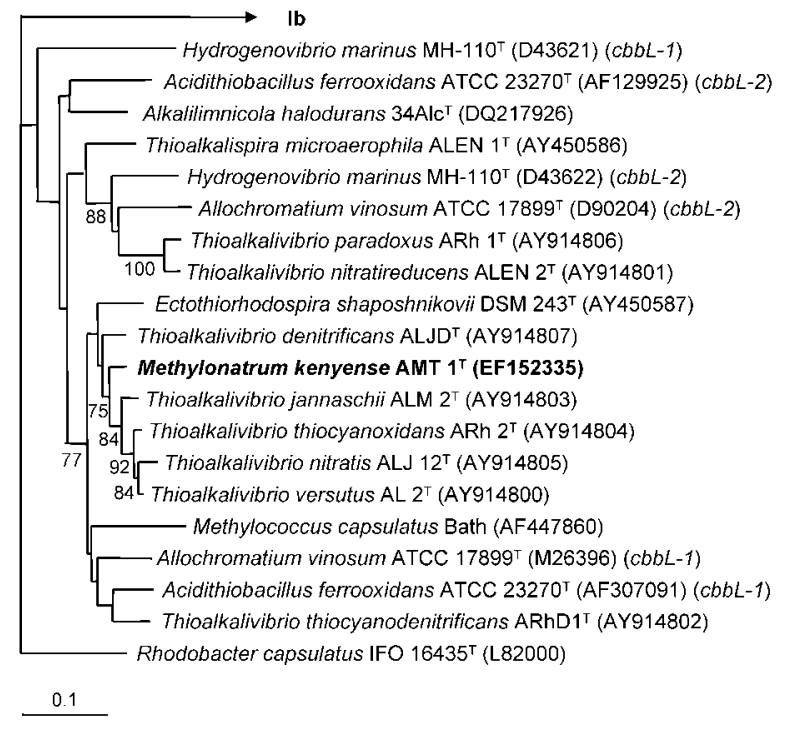

(b)



Fig. 3. Phylogenetic positions of methylotrophic isolates based on translated amino acid analysis of functional genes. (a) Position of haloalkaliphilic isolate AMT $1^{\top}$ based on $c b b L$ gene sequence analysis (large subunit of RuBisCO); (b) position of halophilic strain HMT $1^{\top}$ based on sequence analysis of the mxaF gene (methanol dehydrogenase). Tree topologies and evolutionary distances are given by the neighbour-joining method with Poisson corrections. Numbers at nodes indicate percentage bootstrap values from 1000 replications. Bars, $10 \%$ (a) and $5 \%$ (b) sequence variation.

neutrophilic. $\mathrm{C}_{16: 0}$, cyc $\mathrm{C}_{17: 0}$ and 10-methyl $\mathrm{C}_{16: 0}$ are the dominant cellular fatty acids. The genus belongs to the Gammaproteobacteria. Known habitat is hypersaline chloride-sulfate lakes. Methylohalomonas lacus is the type species.

\section{Description of Methylohalomonas lacus sp. nov.}

Methylohalomonas lacus (la'cus. L. gen. n. lacus of a lake).

Displays the following properties in addition to those described for the genus. Cells are non-motile $(0.5-0.6 \times 1-$

Table 3. Comparative properties of (halo)alkaliphilic methylotrophic bacteria from salt lakes

Strains: 1, HMT $1^{\mathrm{T}}$ (data from this study); 2, AMT $1^{\mathrm{T}}$ and AMT3 (this study); 3, Methylophaga alcalica M39 ${ }^{\mathrm{T}}$ (Doronina et al., 2003a); 4, 'Methylophaga natronica' Bur 2 (Doronina et al., 2003b); 5, 'Ancylobacter natronum' Bur 3 (Doronina et al., 2001); 6, Methylarcula terricola h37 ${ }^{\mathrm{T}}$ (Doronina et al., 2000). RuMP, Ribulose monophosphate pathway; ND, no data available.

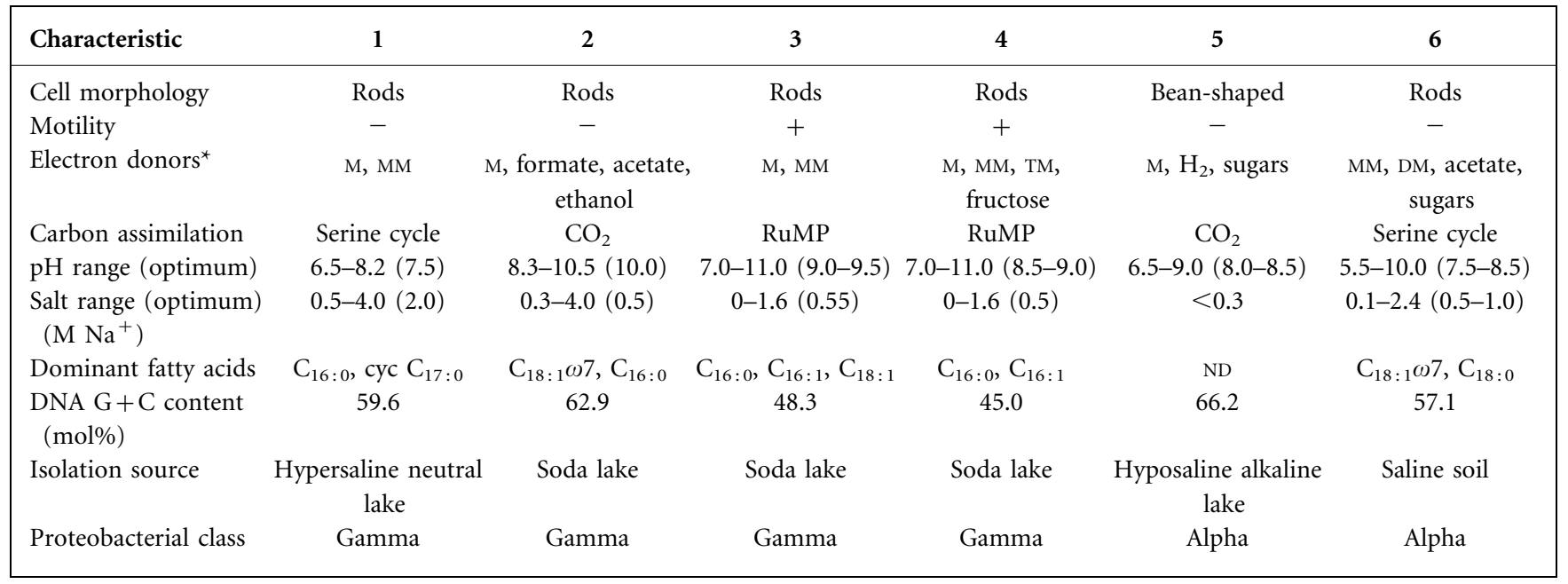

${ }^{*}$ DM, Dimethylamine; M, methanol; MM, methylamine; TM, trimethylamine. 
$3 \mu \mathrm{m}$ ), occurring singly or in short chains, and covered with a layer of EPS-like material. Strictly aerobic, utilizing methanol and methylamine as carbon and energy sources. With methanol, grows at $\mathrm{pH}$ 6.5-8.2 (optimum $\mathrm{pH}$ 7.5). Extremely salt-tolerant, moderate halophile with a $\mathrm{NaCl}$ range for growth between 0.5 and $4 \mathrm{M}$ and an optimum at $2 \mathrm{M}$. Unable to grow autotrophically with $\mathrm{H}_{2}$ or thiosulfate as the energy source. Ammonium serves as a nitrogen source. The $\mathrm{G}+\mathrm{C}$ content in the DNA of the type strain is $59.6 \mathrm{~mol} \%$.

The type strain, HMT $1^{\mathrm{T}}\left(=\right.$ DSM $15733^{\mathrm{T}}=$ NCCB $100208^{\mathrm{T}}$ $=\mathrm{UNIQEM} \mathrm{U} 237^{\mathrm{T}}$ ), was isolated from hypersaline inland lakes in south-western Siberia (Altai, Russia).

\section{Description of Methylonatrum gen. nov.}

Methylonatrum [Me.thy'lo.na.trum. N.Gr. n. methyl (from Gr. n. methu wine and Gr. n. hulê wood) the methyl radical; N.Gr. n. natron arbitrarily derived from the Arabic n. natrun or natron soda; N.L. neut. n. Methylonatrum methyl-group-utilizing, soda (-loving bacterium)].

Cells are Gram-negative, short rods. Obligately aerobic, restricted methylotrophs. Autotrophic Calvin-Benson cycle is used for carbon assimilation during methylotrophic growth. Moderately salt-tolerant and obligately alkaliphilic. $\mathrm{C}_{18: 1} \omega 7$ is the dominant cellular fatty acid. The genus belongs to the Gammaproteobacteria. Known habitat is soda lakes. Methylonatrum kenyense is the type species.

\section{Description of Methylonatrum kenyense sp. nov.}

Methylonatrum kenyense (ken.yen'se. N.L. neut. adj. kenyense pertaining to Kenya, where the type strain was isolated).

Displays the following properties in addition to those described for the genus. Cells are short, coccoid, nonmotile rods $(0.5-0.7 \times 1-1.2 \mu \mathrm{m})$, occurring singly or in pairs. Utilizes methanol, formate, ethanol and acetate as carbon and energy sources. With methanol, grows at $\mathrm{pH}$ 8.3-10.5 (optimum $\mathrm{pH} 10$ ). Extremely salt-tolerant, growing at salt contents between 0.3 and $4 \mathrm{M}^{2}$ total $\mathrm{Na}^{+}$ with an optimum at 0.5-1.0 M. Can not grow autotrophically with $\mathrm{H}_{2}$ or thiosulfate as the energy source. Utilizes ammonium and nitrate as nitrogen sources. $\mathrm{G}+\mathrm{C}$ content in the DNA is $62-62.9 \mathrm{~mol} \%$.

The type strain, AMT $1^{\mathrm{T}}\left(=\mathrm{DSM} 15732^{\mathrm{T}}=\mathrm{NCCB} 100209^{\mathrm{T}}\right.$ $=$ UNIQEM $\left(238^{\mathrm{T}}\right.$ ), was isolated from the soda lake Magadi in Kenya. The closely related strain AMT 3 $(=$ NCCB 100206) originated from soda lakes in the Kulunda Steppe (Altai, Russia).

\section{Acknowledgements}

This work was supported by NWO-RFBR (047.011.2004.010) and RFBR (07-04-00153, 05-04-48058 and 05-04-4864) and by the
Program on Molecular and Cell Biology RAS. We are grateful to M. Stein for compatible solute analysis.

\section{References}

Banciu, H., Sorokin, D. Y., Rijpstra, W. I. C., Sinninghe Damsté, J. S., Galinski, E. A., Takaichi, S., Muyzer, G. \& Kuenen, J. G. (2005). Fatty acid, compatible solute and pigment composition of obligately chemolithoautotrophic alkaliphilic sulfur-oxidizing bacteria from soda lakes. FEMS Microbiol Lett 243, 181-187.

Dedysh, S. N., Smirnova, K. V., Khmelenina, V. N., Suzina, N. E., Liesack, W. \& Trotsenko, Y. A. (2005). Methylotrophic autotrophy in Beijerinckia mobilis. J Bacteriol 187, 3884-3888.

De Ley, J., Cattoir, H. \& Reynaerts, A. (1970). The quantitative measurement of DNA hybridization from renaturation rates. Eur $J$ Biochem 12, 133-142.

Doronina, N. V., Braus-Strohmeyer, S. A., Leisinger, T. \& Trotsenko, Y. A. (1995). Isolation and characterization of a new facultatively methylotrophic bacterium: description of Methylorhabdus multivorans gen. nov., sp. nov. Syst Appl Microbiol 18, 92-98.

Doronina, N. V., Trotsenko, Y. A. \& Tourova, T. P. (2000). Methylarcula marina gen. nov, sp. nov. and Methylarcula terricola sp. nov.: novel aerobic, moderately halophilic, facultatively methylotrophic bacteria from coastal saline environments. Int J Syst Evol Microbiol 50, 1849-1859.

Doronina, N. V., Darmaeva, Ts. D. \& Trotsenko, Yu. A. (2001). Novel aerobic methylotrophic isolates from the soda lakes of the southern Transbaikal region. Microbiology (English translation of Mikrobiologiia) 70, 342-348.

Doronina, N. V., Darmaeva, T. D. \& Trotsenko, Y. A. (2003a). Methylophaga alcalica sp. nov., a novel alkaliphilic and moderately halophilic, obligately methylotrophic bacterium from an East Mongolian soda lake. Int J Syst Evol Microbiol 53, 223-229.

Doronina, N. V., Darmaeva, T. D. \& Trotsenko, Y. A. (2003b). Methylophaga natronica sp. nov., a new alkaliphilic and moderately halophilic, restricted-facultatively methylotrophic bacterium from soda lake of the Southern Transbaikal region. Syst Appl Microbiol 26, 382-389.

Felsenstein, J. (1993). PHYLIP (phylogeny inference package), version 3.53c. Distributed by the author. Department of Genome Sciences, University of Washington, Seattle, USA.

Galinski, E. A. \& Herzog, R. M. (1990). The role of trehalose as a substitute for nitrogen-containing compatible solutes (Ectothiorhodospira halochloris). Arch Microbiol 153, 607-613.

Galinski, E. A. \& Trüper, H. G. (1994). Microbial behaviour in saltstressed ecosystems. FEMS Microbiol Rev 15, 95-108.

Heyer, J., Berger, U., Hardt, M. \& Dunfield, P. F. (2005). Methylohalobius crimeensis gen. nov., sp. nov., a moderately halophilic, methanotrophic bacterium isolated from hypersaline lakes of Crimea. Int J Syst Evol Microbiol 55, 1817-1826.

Joye, S. B., Connell, T. L., Miller, L. G., Oremland, R. S. \& Jellison, R. S. (1999). Oxidation of ammonia and methane in an alkaline, saline lake. Limnol Oceanogr 44, 178-188.

Marmur, J. (1961). A procedure for the isolation of deoxyribonucleic acid from microorganisms. J Mol Biol 3, 208-218.

McDonald, I. R. \& Murrell, J. C. (1997). The methanol dehydrogenase structural gene $m x a F$ and its use as a functional gene probe for methanotrophs and methylotrophs. Appl Environ Microbiol 63, 3218-3224.

Namsaraev, B. B., Zhilina, T. N., Kulyrova, A. V. \& Gorlenko, V. M. (1999). Bacterial methanogenesis in soda lakes of the Southeastern 
Transbaikal region. Microbiology (English translation of Mikrobiologiia) 68, 586-591.

Oremland, R. S., Marsh, L. \& Deswarais, D. L. (1982). Methanogenesis in Big Soda Lake. Appl Environ Microbiol 43, 462-468.

Oren, A. (2002). Halophilic Microorganisms and their Environments. Dordrecht: Kluwer.

Pfennig, N. \& Lippert, K. D. (1966). Über das Vitamin $B_{12}$-Bedürfnis phototropher Schwefelbakterien. Arch Microbiol 55, 245-256 (in German).

Schäfer, H. \& Muyzer, G. (2001). Denaturing gradient gel electrophoresis in marine microbial ecology. Methods Microbiol 30, 426-468.

Sokolov, A. P. \& Trotsenko, Y. A. (1995). Methane consumption in (hyper)saline habitats of Crimea (Ukraine). FEMS Microbiol Ecol 18, 299-303.

Sorokin, D. Yu., Tourova, T. P., Kolganova, T. V., Sjollema, K. A. \& Kuenen, J. G. (2002). Thioalkalispira microaerophila gen. nov., sp. nov., a novel lithoautotrophic, sulfur-oxidizing bacterium from a soda lake. Int J Syst Evol Microbiol 52, 2175-2182.

Sorokin, D. Yu., Gorlenko, V. M., Namsaraev, B. B., Namsaraev, Z. B., Lysenko, A. M., Eshinimaev, B. Ts., Khmelenina, V. N., Trotsenko, Y. A. \& Kuenen, J. G. (2004). Prokaryotic communities of the northeastern Mongolian soda lakes. Hydrobiologia 522, 235-248.

Sorokin, D. Yu., Tourova, T. P., Lysenko, A. M. \& Muyzer, G. (2006). Culturable diversity of halophilic sulfur-oxidizing bacteria in hypersaline habitats. Microbiology 152, 3013-3023.
Spiridonova, E. M., Berg, I. A., Kolganova, T. V., Ivanovsky, R. N., Kuznetsov, B. B. \& Tourova, T. P. (2004). An oligonucleotide primer system for amplification of the ribulose-1,5-bisphosphate carboxylase/oxygenase genes of bacteria of various taxonomic groups. Microbiology (English translation of Mikrobiologiia) 73, 316-325.

Trotsenko, Y. A. \& Khmelenina, V. N. (2002a). Biology of extremophilic and extremotolerant methanotrophs. Arch Microbiol 177, 123-131.

Trotsenko, Y. A. \& Khmelenina, V. N. (2002b). Biology and osmoadaptation of haloalkalitolerant methanotrophs. Microbiology (English translation of Mikrobiologiia) 71, 123-132.

Van de Peer, Y. \& De Wachter, R. (1994). TREECON for Windows: a software package for the construction and drawing of evolutionary trees for the Microsoft Windows environment. Comput Appl Biosci 10, 569-570.

Vargas, C., Kallimanis, A., Koukkou, A. I., Calderona, M. I., Canovas, D., Iglesias-Guerrac, F., Drainas, C., Ventosa, A. \& Nieto, J. J. (2005). Contribution of chemical changes in membrane lipids to the osmoadaptation of the halophilic bacterium Chromohalobacter salexigens. Syst Appl Microbiol 28, 571-581.

Zavarzin, G. A., Zhilina, T. N. \& Kevbrin, V. V. (1999). The alkaliphilic microbial community and its functional diversity. Microbiology (English translation of Mikrobiologiia) 68, 503-521. 